University of Chicago Law School

Chicago Unbound

Public Law and Legal Theory Working Papers

Working Papers

2014

\title{
The Psychology of Corporate Rights
}

Avital Mentovich

Aziz Huq

Moran Cerf

Follow this and additional works at: https://chicagounbound.uchicago.edu/public_law_and_legal_theory

Part of the Law Commons

Chicago Unbound includes both works in progress and final versions of articles. Please be aware that a more recent version of this article may be available on Chicago Unbound, SSRN or elsewhere.

\section{Recommended Citation}

Avital Mentovich, Aziz Huq \& Moran Cerf, "The Psychology of Corporate Rights" (University of Chicago Public Law \& Legal Theory Working Paper No. 497, 2014).

This Working Paper is brought to you for free and open access by the Working Papers at Chicago Unbound. It has been accepted for inclusion in Public Law and Legal Theory Working Papers by an authorized administrator of Chicago Unbound. For more information, please contact unbound@law.uchicago.edu. 


\title{
CHICAGO
}

Public LaW AND Legal TheORY WORKING PAPER NO. 497

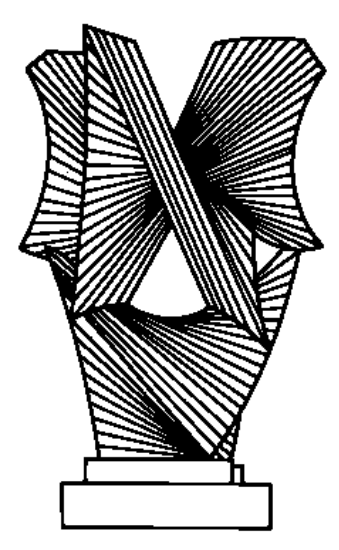

\section{THE PSYCHOLOGY OF CORPORATE RIGHTS}

\author{
Avital Mentovich, Aziz Z. Huq, and Moran Cerf
}

\section{THE LAW SCHOOL THE UNIVERSITY OF CHICAGO}

December 2014

This paper can be downloaded without charge at the Public Law and Legal Theory Working Paper Series:

http://www.law.uchicago.edu/academics/publiclaw/index.html

and The Social Science Research Network Electronic Paper Collection. 
RUNNING HEAD: The Psychology of Corporate Rights

\title{
The Psychology of Corporate Rights
}

\author{
Avital Mentovich \\ University of California, Los Angeles, Psychology Department
}

Aziz Huq

University of Chicago, Law School

Moran Cerf

Kellogg Business School, Northwestern University

Key words: Rights, Corporations, Political Ideology, Moral patiency 


\begin{abstract}
Relying on the corporate personhood doctrine, the U.S. Supreme Court has increasingly expanded the scope of rights granted to corporations and other forms of collective entities. While this trend has received widespread attention in legal scholarship and the media, there is no empirical research examining how people think about the rights of corporations. We investigated this issue in a series of three studies, each exploring a different constitutional right (religious liberty, privacy, and freedom of speech). In each study, we examined people's willingness to grant rights in several types of business contexts (i.e., a 'closely held' family business, a large national corporation, for-profit and non-for-profit companies) and to different types of targets (i.e., employees, owners, and the company as a separate entity). We also looked at whether perceptions of corporate (versus individual) rights are affected by political ideology. Our results demonstrate that people are significantly and consistently less willing to grant the same scope of protection to companies versus people, particularly if these companies are for-profit large corporations. This tendency persisted among both liberals and conservatives. We identified ideological differences in the relations between employee and company rights: these were positively related among conservatives and more conflicting among liberals. Importantly, we found some evidence that people grant rights to companies because they want to protect the rights of individuals. Taken together these results indicate that, psychologically speaking, individuals (and not corporations) are the appropriate recipients of rights.
\end{abstract}




\section{Introduction}

Corporations have enjoyed constitutional rights since the U.S. Supreme Court's decision in Santa Clara County v. Southern Pacific Railroad Company (1886), when the Court in a "causal" aside extended equality protections to a for-profit railroad (Horowitz, 1986). A recent expansion in corporate rights, however, provoked considerable public controversy: the Supreme Court's decision in Citizens United v. FEC (2010), which freed corporations' use of general treasury funds for political advertising, generated a "furor" at the prospect of increasing corporate influence on political life (Levitt, 2010). President Obama called the Citizens United decision a "major victory for big oil, Wall Street banks, health insurance companies, and other powerful interests that marshal their power every day in Washington to drown out the voices of everyday Americans." (Kang, 2012). The decision even generated appeals for a constitutional amendment (Blackstone, 2013). More recently, in Burwell v. Hobby Lobby (2013), the Supreme Court recognized the religious liberty interest of closely-held for-profit corporations. That decision is also likely to prove divisive as further religious liberty challenges are brought by for-profit corporations, including the minority (6 per cent) of pharmacists who object to birth control measures such as interuterine devices (Davidson et al., 2010).

Despite its divisiveness, judicial recognition of corporate rights does not rest on robust theoretical or empirical foundations (Garrett, 2014). The Supreme Court has never elaborated its holding in Santa Clara County. As early as 1926, John Dewey observed that courts tend to recognize corporate personhood for some purposes, but not others, based largely on "extraneous dogmas and ideas" drawn "from psychology or philosophy or what not" (Dewey 1926, p. 657). Dewey therefore concluded that the judicial recognition of 


\section{RUNNING HEAD: The Psychology of Corporate Rights}

corporate personhood could not be understood without examining the way in which widely held assumptions influenced the law. Dewey's methodological concern has been echoed by subsequent generations of legal scholars and social scientists who have called for "behavioral realism" in legal theory thorough rigorous attention to how such theory corresponds with scientific knowledge about human mind and behavior (Krieger \& Fiske, 2006; Kang \& Banaji, 2006; Mentovich \& Jost, 2008).

This present study pursues the concerns identified by Dewey and others by exploring the psychology of corporate rights. Its central aim is to identify the predicate grounds on which individuals treat corporations like or unlike natural persons. Our focus is on three constitutional rights - religious liberty, free speech, and privacy - that have been a focus of public attention. A better understanding of the psychological bases of corporate rights' recognition may help predict whether and when judicial endowment of corporate rights will spark protest. Although a richer account of the psychology of corporate rights may not directly feed into the law, it may also inform legal reasoning. For example, the majority and the dissent in Hobby Lobby differed over how to interpret the word "person" in the Religious Freedom Restoration Act of 1993. The majority read that word to include closely held forprofit corporations, but did not rule that the term included larger, publicly traded corporations. The dissent, in contrast, read the term "person" to reach only not-for-profit corporations. An understanding of when — and why — individuals see corporations as rights-holders may inform how the statutory language is properly read, and thus whether the majority or the dissent more accurately capture the original usage of the term.

Systematic empirical exploration of the psychology of corporate rights has received little academic attention to date - in contrast to their economic, philosophical and legal 
dimensions. Only a handful of recent psychological works offer contributions regarding how individuals attribute group (as opposed to individual) mind, as well as how such attributions impact inferred intentionality and moral responsibility of collective entities in comparison to the persons who constitute them (Tyler \& Mentovich, 2011; Waytz \&Young, 2012). Extending these lines of inquiry, we first examine the relationship between corporate and individual rights. As public discourse (and Supreme Court ruling) often follow ideological lines, we further analyze how political preferences influence the psychological dynamics underlie granting rights to corporations. Finally, we examine the potential reasons for which people are willing to extend rights to corporations.

\section{The Legal Rights of Corporations}

Corporate rights vary in practice along two dimensions. First, corporations have some rights but not others. For example, corporate claims to equal protection under the law, free speech, privacy, and-most recently—religious liberty have all been recognized in court. In contrast, corporate claims to rights against self-incrimination, to the privileges and immunities of state citizenship, and to individual liberty have not been recognized (Garrett, 2014). Second, different species of corporations obtain different levels of judicial protection (Bhagwati, 2011). In Hobby Lobby, for example, the Court was divided over whether any for-profit corporations could bring religious liberty claims in court. In a pre-Citizens United campaign finance decision, FEC v. Massachusetts Citizens for Life, Inc., (1986), the Supreme Court distinguished for the purposes of campaign finance regulation between forprofit entities, and a non-profit, non-stock corporation formed solely for the purpose of engaging in political speech and advocacy. More recently, the Court has created different regimes for the individual members of labor unions and for-profit corporations: The former 
have a right to opt out of funding political speech they do not support, while the latter do not (Sachs, 2012).

It is important to note that not all consequences of corporate personhood are disputed, and not all are sought after. On the one hand, few would argue that corporations should not have personhood for the purposes of entering and enforcing contracts. On the other hand, while much doubt obtains about corporate rights, there is no analogous skepticism about corporate criminal responsibilities — at least in theory (Green, 1991). Corporations have been considered persons for the purposes of criminal prosecution since the Middle Ages (Dubber, 2013), although recent studies suggest that prosecutions are rarely successful (Garrett, 2007; Laufer, 2006). Criminal liability is arguably distinct from the sort of personhood necessary for the recognition of rights (Isaacs, 2013). But for the purposes of criminal adjudication, corporations do benefit from the procedural protections of the Bill of Rights (Henning, 1996).

There is no theoretical, normative justification for the observed variation in corporate rights - or at least none has yet been offered by the Supreme Court (Garrett, 2014). Philosophical justifications have been offered for treating corporations as "members of the moral community of equal standing" (French, 1979, p. 207). This conclusion is sharply contested by Velasquez (1983), who argues that it is merely a confused way of attributing responsibility to individual participants in the corporation. Economic theory, moreover, does not fill the gap (Lee, 2009). Jensen and Meckling's (1975) canonical article, for example, parsimoniously defines a corporation as a "nexus of contracts" (for applications to law, see Easterbrook \& Fischel, 1989; Klausner, 1995); in another classic treatment, Hart and Moore (1988) focus on the firm as a solution to problems arising from contractual incompleteness. 
In a similar foundational analysis, Coase argued that the size of a firm would be a function of the relative costs of internalizing a transaction within its boundaries versus entering the same transaction in the marketplace: Firms would grow, that is, to internalize transactions when it was efficient to do so, and otherwise rely on the market (Coase 1937). These contractual-based analytic frameworks can be effectively applied to predict the scale of enterprises, and, for example to explain why some firms are small and family owned, while others are expansive and publicly traded (Villalonga \& Amit, 2010; Williamson, 2003). They provide little guidance, however, as to when (or why) more fundamental rights of corporations should be recognized.

Recent changes to the scope of corporate constitutional rights thus cannot be explained by any theoretical framework of rights derived from constitutional law, economic theory, or philosophical accounts. These changes have been most pronounced in the context of three kinds of corporate rights: speech, religious freedom, and privacy ${ }^{1}$. First, with respect to free speech rights, corporate candidate contributions, as well as independent political expenditures, have been outlawed since the Tillman Act of 1907 (2 U.S.C. $\S 441 b$ ). The prohibition has been justified both as an effort to prevent firms' managers from supporting policies using shareholders' resources, as well as to prevent large advantage that corporations have in the political competition over regular citizens (Sitkoff, 2002). Beginning in 2007, the Supreme Court issued a series of holdings that granted corporations First Amendment rights and undermined the Tillman Act (see FEC v. Wisconsin Right to Life, 2007; Citizens United v. FEC, 2010; McCutcheon v. Federal Election Commission, 2014). The practical effect of these decisions is to endow corporations with First

\footnotetext{
${ }^{1}$ The structure of claim, however, is slightly different than the claims of speech and religious rights: In respect to privacy, corporations have not asserted their own interests, but rather resisted disclosures on the ground that individual third parties' interests will be compromised.
} 
Amendment rights to unlimited campaign expenditures and to permit only weak legal limitations to candidate contributions.

Second, in 2014, the Court recognized a corporate right to religious freedom in Burwell v. Hobby Lobby. The Court held that closely held corporations could resist compliance with federal healthcare coverage mandates on the basis of sincerely held religious beliefs. Hobby Lobby concerned the question of whether corporations would have to pay for certain forms of medical coverage. A subsequent Supreme Court order seemingly extended the right of noncompliance on religious grounds by allowing organizations to refuse even to sign a form authorizing a third party to provide contraceptive coverage for women employees (Wheaton College v. Burwell, 2014). The range of entities that now possess constitutional rights is also unclear. Justice Samual Alito's logic in the Hobby Lobby majority opinion seems to extend to larger, publicly traded corporations, but the Court expressly refrained from holding that such entities had religious liberty rights. By contrast, a dissent in the case would have limited such rights to non-profit entities only.

The right recognized in Hobby Lobby is nevertheless limited in two respects. First, the decision was an interpretation of a federal statute, the Religious Freedom Restoration Act of 1993, not the Constitution. Nevertheless, the majority opinion in Hobby Lobby extensively cited cases interpreting the Constitution to reach its holding. Second, the majority limited its ruling to closely held corporations, rather than larger, publicly traded ones. Nevertheless, both minority and majority opinions relied on the doctrine of legal personhood and deemed collective entities as appropriate recipients of religious rights. They only differ in the sort of organizations that deserve them. Futhermore, the Hobby Lobby 
decision is likely to precipitate further claims by corporations for exceptions from generally applicable laws based on religious belief.

A third domain in which corporations have claimed increasing rights concerns privacy from electronic surveillance by the government. The state can rely on telecommunications' aggregations of electronic communications and metadata generated by communication and internet use to intrude on its citizens and foreign individuals (Solove, 2002). Individual privacy, therefore, is determined by corporate policy in regard to government requests for data. Corporations sometimes act to protect individual privacy. In June 2013, for example, both Microsoft and Google filed lawsuits challenging aspects of the U.S. government's requests for communications metadata (Carroll, 2013). The secure e-mail service Lavabit did not assert a privacy-derived right against government requests for data. Instead, it closed rather than comply with those requests (Perlroth \& Shane, 2013). Unlike religious or speech rights, the majority of privacy claims by corporations have been raised to defend the rights of employees. Thus, privacy, it seems to us, has a slightly different valence to speech and religious freedom. Whereas corporate speech and corporate religious freedom may have a conservative cast as policy goals, the privacy interests pursued by Microsoft, Google, and Lavabit have either a liberal or a libertarian cast.

\section{Empirical Research on the Social Psychology of Corporate Rights}

There is little research into the conditions under which individuals tend to recognize the rights of corporations. Some studies suggest that individuals evaluate corporates according to normative criteria, and alter their behavior based on these assessments. Prior work on procedural justice suggests that perceptions of corporate entities, and their 


\section{RUNNING HEAD: The Psychology of Corporate Rights}

compliance with norms of procedural justice and fairness, influences employee compliance with internal rules (Tyler \& Blader, 2005).

While not exploring this issue directly, works about the attribution of mind to collective entities can have implications to the issue of corporate rights. In a series of studies, Waytz and Young (2012) explored the relations between attributions of mind to groups and to their individual members, as well as the implications of these relations to perceptions of moral responsibility. In one study, participants were presented with several groups ranging from car owners, to the U.S. Congress, to McDonald's Corp. Participants were asked how much mind they attribute to these groups versus their individual group members. The study - which is not focused on corporate entities - identifies a negative correlation between attributions of group mind and attributions of individual mind. Importantly, Waytz and Young further show that greater attributions of mind lead to greater attributions of responsibility because "perceivers are capable of attributing only a finite amount of mind" (p.83). Similarly, Morewedge et al. (2013) find that attribution of mind to individual members of a group is inversely related to the size of the group to which an individual belonged. Menon et al. (1999), however, find cultural differences in the strength of group agency attributions, with East Asian respondents being more willing than North American respondents to discern group agency.

It therefore seems that the lack of ability to attribute mental life to groups (particularly to groups that are big in size and lack cohesion) renders them less appropriate to the attribution of moral agency, responsibility, and culpability (see also Tyler \& Mentovich, 2011; Mentovich \& Cerf, 2014). We argue that this deficiency should also impact people's willingness to grant rights to collective entities. Though, unlike moral 
agency, the reception of rights is rooted in moral patency and the desire to defend targets from potential suffering or wrongdoing (see Gray \& Wenger, 2009), both moral agency and patiency seem to be anchored in the existence of mental life (see Gray, Young \& Waytz, 2012 for a similar analysis). For the same reasons it is difficult for people to attribute mental life to collectives - and thus view them capable of forming intent, and being morally responsible - it would be difficult to see collectives as suffer harm, require protection, and deserve rights at the same degree that natural people do.

The above conclusion may explain public reaction to the rulings of Citizens' United and Hobby Lobby but it is not directly supported by empirical research. With the exception of public opinion surveys, we have been unable to identify any prior empirical work that analyzes the predicates for public recognition of corporate rights. In effect, almost ninety years after Dewey's claims, we are still not much better informed as to why and when corporate rights will be generally endorsed. An understanding of public judgments about corporate rights is relevant to the stability of decisions such as Citizens' United and Hobby Lobby, as much as it is relevant to the psychology of rights more generally. It seems that both legal discussion and empirical research on the issue of corporate (versus individual) rights are deeply undertheorized and underexplored. The current research seeks to provide the first step in the exploration of this issue.

\section{Overview of the Present Research}

In a series of three studies, we explored whether, and to what extent, people deem corporate entities, as opposed to individuals, as deserving of fundamental rights. We analyzed three slightly different rights: religious liberty in study one, privacy in study two, and freedom of speech in study three. In each study the organizational context was 


\section{RUNNING HEAD: The Psychology of Corporate Rights}

manipulated such that participants were presented with five different business settings. These included three traditional for-profit businesses (a family owned small company, a local publicly traded chain, and a national mega corporation) as well as two other organizations that matched to the context of the specific right at stake (e.g., a church in the religious freedom context and a newspaper in the context of freedom of speech).

Participants in each study were asked to rate the extent to which they believed three target recipients within each of the different organizations presented to them deserved to receive the given right. These targets included the company's owners (or a close analog when ownership did not exist), the company's employees, and the company itself as a separate legal entity. It is important to note that we did not employ a tradeoff between individual and entity rights in the research design. That is, the rights of one target (e.g., the employees) did not come at the expense of another target (i.e., the company itself). Instead, participants could grant as much of a given right to a target as they saw fit. This design ensures that we assess how people naturally think about company and individual rights other than how they prioritize them.

\section{Study 1 - Religious Liberty}

\section{Participants}

One hundred and eleven participants were recruited online using Amazon Mechanical Turk ('MTurk') platform (Seattle, WA). To be eligible to participate in the study Mturk participants had to conduct at least 50 studies prior to this one, have an approval rate equal or higher than $95 \%$, and to have a U.S. IP address. Fifteen participants failed the attention check questions (described below) and were therefore excluded from further analyses. Our final sample, comprised of 96 individuals, was demographically 
diverse: $50 \%$ were females, $84 \%$ whites, Mean age $=36.99(S D=13.3), 28.1 \%$ of participants defined themselves as somewhat religious and $25.3 \%$ describe themselves as extremely religious, $12.5 \%$ participants had high school education, $39.6 \%$ had post high school (but no college) degree, and $41.5 \%$ had a college degree.

Procedure and Materials

Participants were recruited into a study entitled "Your opinions about religious liberty in the U.S." Participants were first asked several demographic questions; they then were allowed to proceed to the experimental scenarios, which included a description of five different organizational contexts. These five prompts were presented in a random order.

Political orientation: as part of the demographic section participants indicated how liberal conservative they see themselves on a scale ranging from 1 ('extremely liberal') to 7 ('extremely conservative'), $M=3.65 ; S D=1.79$.

Attention Check: As part of the demographic section we applied two attention check test, typically used with online participants (see, e.g., Waytz and Young, 2012). In the first test participants were told: "some participants in surveys fail to pay attention to the questions asked and answer automatically. This can affect the results and skew the data. In order to prevent this situation we created a control question. In this question we ask you not to answer anything and simply continue to the next page. Non-attentive participants will end up selecting hobbies from the below list despite the above instructions." This question was followed with a question asking: "Which activities do you engage in regularly (check all that apply)?" Participants who provided any answer to this question were excluded due to failing the attention check. 
A second attention check told participants that "For sake of validation, please type the same number you use for this question as your answer for the next one (ignoring the question about 'number of times the letter 'a' appears in the sentence)." Participants who showed discrepancies in their answers were also excluded from further analyses.

Experimental scenarios: Participants were presented with different types business settings and were asked to report the extent to which several targets within each setting deserve religious liberty rights. These business settings included the following descriptions:

Family owned store: "Consider a corner grocery store located in the small town of Davis, Nebraska. The store is owned by Ben and Eva Gordon. Apart from the two owners, the store has 3 full-time employees. The store is a legally separate entity incorporated under state law."

Local Chain: "Consider a local chain of several grocery stores that are located within twenty miles of each other, within the state of Nevada. The chain employs about 700 people, and has a management team that includes Chief Executive Officer, Chief Finance Officer, as well as a team of 50 local branch managers. The stores are part of a single company. The chain is a legally separate entity incorporated under state law. The equity in that company is not publicly traded, but is held by a small group of individual owners."

National Chain: "Consider a national chain of 1500 grocery stores that has branches across the Atlantic seaboard, the Midwest, South and Pacific coasts. The chain has about 100 employees in each branch (150,000 employees altogether across the country). The chain is managed by a team that includes a Chief Executive Officer, a Chief Finance Officer, and 150 local branch managers. The chain is a legally separate entity incorporated under state law. The equity in the company is publicly traded on the New York Stock Exchange." 
Secular non-profit: "Consider a not-for-profit organization that operates a food bank that serves both urban and rural communities across New Mexico, Oklahoma, Texas, and Arkansas. The food bank has 500 volunteers and is managed by a team of four presidents - each overseeing a different state."

Religious non-profit (church): "Consider a local church that also operates social services and provides aid to the needy in the community. The church has branches across one 3 adjacent towns in South Dakota. The church has about 500 employees, including clergy and lay employees. It is managed by a group of four spiritual leaders, rotating in their positions every two years."

Targets: After they had read each of these prompts, participants were asked to "rate to which extent the following [targets] have a right for religious liberty," on a scale ranging from 1 (not at all) to 7 (very much). The targets always included the company's owners (in the case of the food bank we used the presidents as a closest substitute for owners, and in the case of the church we used the pastors); the company's employees (in the case of the food bank we used volunteers); and the company itself as a separate legal entity.

\section{Results and Discussion}

We conducted a 5 (business setting) x 3 (target identity) Repeated Measures ANOVA on the participants' ratings of targets' deservingness of religious liberty rights. The results of this analysis are presented in Figure 1.

\section{----- Figure 1 approximately here ------}

As Figure 1 shows, our analysis yielded a strong main effect of target identity, $F(2,182)=99.13, p<.001, \eta^{2}=.53$. People consistently and strongly preferred granting people - whether they were asked about owners $(M=6.59, S E=.1)$ or about employees $(M$ 
$=6.6, S E=.09)-$ religious liberty rights. In contrast, their preference for corporate rights was much weaker $(M=4.29, S E=.21)$.

In addition, the results revealed a significant target by business setting interaction $F(8,728)=21.4, p<.0001, \eta p^{2}=.19$. While respondents' desire to maintain religious liberty rights of employees or owners remained constant across settings, they were significantly more willing to give religious liberty rights to non-profit companies (and in particular the church, rather than the non-profit) compared with for-profit companies, $F(4,364)=22.96, p$ $<.001, \eta p^{2}=.19$

Political ideology: As the issue of company or corporate rights is often seen as affected by the ideological divide, we explored the role of political ideology in predicting these results. To this purpose we created two political ideology groups from our continuous political affiliation variable: a liberals group (comprised of participants who scores between 1 and 3 in the political ideology scale, $N=44$ ) and a conservative group (comprised of participants who score between 4 and 7 in the political ideology scale, $N=52$ ). We then conducted a 2 (political ideology) X 5 (business settings) X 3 (target identity) mixed design ANOVA. Results indicated that there was a significant yet small interaction effect of political orientation by business setting and target identity, $F(8,720)=2.05, p=.03, \eta p^{2}$ $=.02$. Results of this analysis are presented in Figures $2 \mathrm{a}$ and $2 \mathrm{~b}$.

Figures $2 \mathrm{a}$ and $2 \mathrm{~b}$ approximately here

As can be seen in Figures $2 \mathrm{a}$ and $2 \mathrm{~b}$, liberals and conservative differed in respect to how much religious liberty rights they granted to employees and owners (where liberals scored slightly higher than their conservative counterparts), and also in respect to how much religious rights they assign to for-profit companies (where conservatives scored slightly 


\section{RUNNING HEAD: The Psychology of Corporate Rights}

higher than their liberal counterparts). However, for both groups there was a strong and consistent preference to grant religious liberty rights to individuals (employees or owners) rather than companies themselves.

The relations between company and employee rights: Following Waytz and Young (2012), we examined the relations between individual and company rights. Waytz and Young's findings indicated the existence of negative relations between groups and group members in the domain of moral responsibility. We sought to examine whether the same relations exist in the case of moral privileges of civic rights. As participants' scores showed little variation in the for-profit businesses (see Figure 1), our analysis was focused on the family owned business. We fitted a linear regression model in which participants' scores of employees religious rights (centered) were regressed onto their scores of the company's religious rights. This analysis identified no relations between employees and company rights, $B=-.12, \beta=-.052, p=\mathrm{n} / \mathrm{s}$. We did, however, find an interaction between political ideology (centered) and the relations between employees and company rights, $B=.31, S E=.157, \beta$ $=.21, p=.05$. The results of this analysis are plotted in Figure 3 .

---- put Figure 3 about here-----

As can be seen in Figure 3, the relation between employee and company rights varied as a function of ideological leaning. For liberals, the two stand in contrast. That is, the more they supported religious rights of employees the less they supported religious rights of companies. For conservatives, however, company and employee rights were positively related and the more they endorsed religious liberty rights of employees the more they endorsed these rights in the context of the company itself. It is important to recall here that the research design did not posit a trade-off between corporate and individual rights. The 


\section{RUNNING HEAD: The Psychology of Corporate Rights}

interactions observed in Figure 3, therefore, reflect divergent and convergent views about individual and corporate rights, not different ways of resolving a tension set up in the research instrument.

In net, these results suggest that people seem to consider individuals as the more appropriate receivers of religious rights compared with organizations (particularly for-profit businesses). The tendency to prefer granting rights to individuals rather than to collective or business entities was extremely robust. It was not eliminated when participants considered a non-profit organization, and even when the religious liberty of church was at stake. In addition, the precise structure of for-profit business had no influence on participants, who viewed all forms of for-profit businesses as the least deserving of religious liberty rights. Non-profit businesses and particularly the church were deemed as more deserving of religious liberty, but never to the extent of individuals.

Moreover, political ideology had very little influence on the above result. Conservative respondents showed only slightly greater willingness to grant for-profit corporations more religious liberty rights. The most significant difference between these ideological groups is not in the absolute level of conservatives and liberals' support for religious liberty for companies, but rather how they seem to think about company and individuals rights. For conservatives, these two species of rights tend to be related; for liberals, either one or the other is present.

\section{Study 2 - Privacy}

Study 2 extended the framework of inquiry applied to religious liberty in Study 1 to privacy. At least in early 2014, when these studies were conducted, religious liberty may have received more media attention. It also may be perceived as unique because of the 


\section{RUNNING HEAD: The Psychology of Corporate Rights}

distinctive role of religion in many individual lives (but few corporate settings). Hence, the design of Study 2 was very similar in design to Study 1 but examined a different basic right of privacy. Like in Study 1, participant were presented with several hypotheticals concerning a diverse array of corporate entities, and then asked to evaluate the extent to which given targets deserve privacy rights.

\section{Participants}

One hundred and fifty participants were recruited online using Mturk platform, employing the same eligibility criteria as in Study 1. Twenty-eight participants failed the attention-check filters (identical to those used in study 1), and were thus excluded from further analyses. The final sample was demographically diverse: (65 males, 56 females; Age range 18-73, $M_{\text {age }}=35.98, S D=13.79 ; 50.8 \%$ reported having at least a Bachelor's degree). Procedure and Materials

The procedure and materials used were similar to those of study 1. Participants were presented five corporate entities (in a random order), and then asked to rate the extent to which these companies' owners, employees, and the entity itself deserved privacy rights.

Experimental scenarios: the three for-profit businesses were identical to those used in study 1 and included a family owned store, a local chain, and a national mega chain. We omitted the non-profit and the church hypotheticals used in Study 1, which were keyed to the religious context, and included two additional businesses that were described as follows:

Newspaper: Consider a daily newspaper published in Washington DC. The newspaper has about 300 employees, including journalists and editorial staff and is 
published in DC daily since 1881. The newspaper is owned by the Silver family that has several other newspapers and media outlets. $^{2}$

Mental Health Center: Consider a mental health center that operates in several locations across California. The center has about 500 employees, including psychiatrists, psychologists and other staff members, and is managed by a president who oversees all the locations.

Targets: In each of the scenarios participants were asked to 'rate to which extent the following [targets] have privacy rights', on a scale ranging from 1 (not at all) to 7 (very much). The targets always included the company's owners (in the case of mental health center we asked about the presidents of the center); the company's employees, and the company itself as a separate legal entity.

Results and Discussion

We conducted a $3 \times 5$ repeated measure ANOVA similar to the one employed in study 1 . The results of this study are presented in Figure 4. This analysis yielded a robust effect of the target identity, $F(2,240)=101.67, p<.001, \eta^{2}=.46$, replicating Study 1 in respect to a different right. That is, participants were much less inclined to grant privacy rights to businesses as a separate legal entity, compared with their owners and employees.

\section{----- Figure 4 approximately here ------}

In addition, differences once more emerged between different kinds of corporate entities, as indicated by a significant target identity by business context interaction, $F(8,960)$ $=5.95, p<.001, \eta^{2} p=.05$. Participants were least likely to grant to privacy rights to the large national corporation, and were most likely to grant these rights to the family-owned store

\footnotetext{
2 We included a newspaper for two reasons. First, news reporting can implicate the privacy interests of sources as well as targets of journalism. Second, newspapers are also an obvious object of analysis for free speech rights, the subject of Study 3 . Hence, their inclusion here facilitates cross-study comparisons.
} 


\section{RUNNING HEAD: The Psychology of Corporate Rights}

and the mental-health center. It bears emphasis, however, that these differences were substantially smaller than the difference between companies and individuals (owners and employees). Interestingly, while in the context of religious liberty participants showed no difference in their desire to grant religious rights to employees versus owners, in the context of privacy, they were more willing to grant rights to employees compared with owners $F(1,120)=20.38, p<.001, \eta^{2}=.14$.

Political ideology: As in Study 1, we divided participants into two groups: Liberals (who scored between 1 and 3 on the political ideology scale, $n=65$ ), and conservatives (who scored between 4 and 6 on the political ideology scale $n=57)$. We then conducted a 2 (political ideology) x 5 (business settings) x 3 (target identity) mixed design ANOVA. Results indicated only ideology by target identity interaction, $F(2,238)=3.106, p=.046, \eta^{2} p$ $=.025$. This showed that conservatives were slightly, albeit consistently, more likely to grant privacy rights to all companies at stake $(M=4.76, S E=.24)$ compared with liberals $(M=$ $4.2, S E=.23$ ). However both groups way equally (and more) likely to grant privacy rights to employees $\left(M_{\mathrm{lib}}=6.35, \mathrm{SE}=.11 ; M_{\mathrm{con}}=6.27, S E=.12\right)$, and owners $\left(M_{\mathrm{lib}}=5.96, S E=.15\right.$; $\left.M_{\mathrm{con}}=5.97, \mathrm{SE}=.16\right)$.

The relations between company and employee rights: We conducted the same regression analysis performed in study 1 . This analysis yielded the same political ideology by employee rights interactions $(B=.22, S E=.12, \beta=.17, p=.06)$. Again, the relations between employees and company privacy rights were different among liberals and conservatives. For liberals, corporate and employee rights were negatively related. For conservatives, they were positively related. 
In summary, study 2 generated results that echoed the main findings of Study 1 in a different context of a right to privacy. Results suggest that the main factor influencing granting privacy rights is whether the recipients of these protections are real people or artificial legal entities like businesses or corporations. While there is variation in people's willingness to grant companies privacy rights as a function of the business structure (where larger corporations are seen even less deserving for such rights) and goals (where organizations like mental health center and newspaper are seen as slightly more deserving of such rights), as well as political orientation (where conservatives are more inclined to give privacy rights to businesses), the main distinction people seem to make is between individuals and businesses. In addition, we also replicated the results of study 1 with regard to how ideology impacts the relations between employee and company rights. Whereas conservatives seem to not see any contradiction between these two elements liberals hold a more contrasting views according to which company rights undermine the rights of employees.

\section{Study 3 - Freedom of Speech}

The purpose of study 3 is twofold. First, we examine whether the results of studies 1 and 2 can be replicated in a related but distinct context of freedom of speech. The idea that companies deserve free speech as citizens recently came into prominence after the Supreme Court ruling in the case of Citizens' United v. FEC (2010). The Supreme Court in that case held that independent corporate expenditures received First Amendment protection in that case. The vigorous negative response to that opinion raises a question of how aligned judicial and public preferences concerning corporate rights in the speech context are. Second, in this study, we extend the inquiry of Studies 1 and 2 by exploring the reasons underlying 


\section{RUNNING HEAD: The Psychology of Corporate Rights}

people judgments of companies' deservingness of rights. More specifically, we analyze two hypotheses: first, that individuals recognize corporate rights because they want to protect corporations; and second that they recognize such rights because they believe that such recognition will conduce to the protection of individual rights. The first hypothesis, that is, implies that corporate rights are an intrinsic good, whereas the second one suggests they are an instrumental good.

\section{Participants}

One hundred participants were recruited online form Mturk platform, using the same eligibility criteria as in study 1 and 2 and were paid $\$ .5$ for participation. Twelve participants failed the attention-check filters (identical to those used in study 1 and 2), and were thus excluded further analyses. The final sample was demographically diverse: $63.6 \%$ males, age range from 19-72 $(M=36.2, S D=14$; mean political ideology $=3.52, S D=1.7)$.

\section{Procedure and Materials}

The procedure and materials used were similar to those of study 1 and 2, but were adapted to the context of free speech. The descriptions of the three for-profit businesses were identical to those used in study 2 . We also included an identical description of a newspaper as a goal-unique business that was included in study 2. In addition, participants were presented with another non-profit organization using the following description:

Non-profit organization: Consider a not-for-profit organization called 'Democracy Watch' that works to promote democracy and transparency in U.S government and state institutions. The NGO has 500 volunteers and is managed by a team of four presidents each overseeing a different state. 
Targets: In each of the scenarios participants were asked to 'rate to which extent the following [targets] have privacy rights', on a scale ranging from 1 (not at all) to 7 (very much). The targets always included the company's owners (in the non-profit we used the presidents), the company's employees (in the case of the non-profit we used volunteers), and the company itself as a separate legal entity.

Mediators: to assess the reasons underlying participants' desire (or refusal) to grant rights to corporations, we assessed two potential explanations. After participants completed the rating of targets' deservingness of free speech rights in each of the five scenario we asked them to think again about three of the given corporate entities previously presented to them: the national chain, the newspaper, and the non-profit democracy watch. We also provided a brief summary of the information previously given about these organizations. Next, in each of these organizations participants were asked how much they agree/ disagree that the given organization (the relevant name was provided) as a separate entity should be given free speech rights to 'to protect the free speech of American citizens' and 'to to protect the free speech of American businesses'. Reponses were given on a scale ranging from 1 (=strongly disagree) to 7 (=strongly agree).

\section{Results and Discussion}

Study 3 generated results that track in large measure those of studies 1 and 2. To begin with, the result of a $3 \times 5$ repeated measure ANOVA are presented in figure 5. This analysis revealed a main effect of target identity, $F(2,170)=13.21, p<.001, \eta^{2}=.14$, suggesting that participants were less likely to grant free speech rights to companies versus their owners of employees. Again, there was a significant target identity by business context interaction, $F(8,680)=1.95, p=.05, \eta^{2} p=.025$. Participants, that is, were more likely to 


\section{RUNNING HEAD: The Psychology of Corporate Rights}

grant free speech rights to the newspaper and the non-profit organization, compared with the three for-profit businesses. Nevertheless, as in studies 1 and 2, in all the hypotheticals, participants always preferred the free speech rights of individuals (employees and owners) compared with the free speech rights of organizations. Interestingly, in the free speech context participants showed significant preference for the free speech rights of owners, rather than employees, $F(1,85)=5.11, p=.02, \eta^{2}=.06$.

put Figure 5 about here

Political ideology: As in study 1 and 2 we created two political ideology groups: Liberals (who scored 1-3 on the political ideology scale, $n=45$ ), and conservatives (two scored 4-6 on the political ideology scale $n=43$ ). We then conducted a 2 (political ideology) x 5 (business settings) x 3 (target identity) mixed design ANOVA. As in Study 2, results indicated only an ideology by target identity interaction, $F(2,168)=3.106, p=.007, \eta^{2} p$ $=.057$. Conservatives were significantly more likely to grant privacy rights to all companies at stake $(M=6.01, S E=.23)$ compared with liberals $(M=5.38, S E=.23)$. In addition, conservatives were less likely to give free speech rights to both owners and employees ( $M_{\text {own }}$ $\left.=6.35, S E=.13 ; M_{e m p}=6.14, \mathrm{SE}=.17\right)$ compared with their liberal counterparts $\left(M_{\text {own }}=\right.$ $\left.6.51, S E=.13 ; M_{e m p}=6.29, \mathrm{SE}=.17\right)$.

The relations between company and employee rights: We conducted the same regression analysis performed in studies 1 and 2. That is, we regressed participants' political ideology (centered), participants' scores of the grocery store employees' deservingness of free speech rights (centered), and their interaction term, on ratings of the grocery store deservingness of free speech rights as a separate entity. This analysis showed yet again a significant political ideology by employee rights interaction, $B=.295, S E=.12, \beta=.26, p$ 


\section{RUNNING HEAD: The Psychology of Corporate Rights}

$=.014$. The interaction revealed that for conservatives the relations between employees and company free speech rights were positively related and for liberals they showed a slight negative skew (see graph 2 in supplement materials).

What explains people's desire to grant free speech rights to companies? To address this question we conducted 3 regression analyses in which participants' ratings of whether free speech rights for a given company (i.e., the national chain, the mental health center, and the newspaper) are needed to defend the rights of citizens and business were entered as predictor of their willingness to grant rights to the relevant collective entity. The results of these analyses are summarized on table 1 . As can be seen in table 1, while there is some support that at least in the context of a newspaper participants' willingness to grant free speech rights was related to their desire to protect businesses, participants' desire to protect citizens' was a more consistent and robust predictor.

----- put table 1 about here------

\section{Discussion}

The Supreme Court's recent forays into corporate rights in Citizens' United v. FEC (2010) and Burwell v. Hobby Lobby (2014), inter alia, have provoked considerable public protest, and in one instance calls for a constitutional amendment (Blackstone, 2013). With both Citizens' United and Hobby Lobby, however, there was some reason to doubt the practical importance of the ruling. As Kang (2012) has observed, much of the practical effect of Citizens' United had been anticipated and realized in the Court's earlier opinion in Wisconsin Right to Life v. FEC (2009); and Justice Alito's majority opinion in Hobby Lobby was at pains to stress that compliance with the ruling did not require any diminution of employees' access to mandated healthcare coverage. Nevertheless, despite some evidence 


\section{RUNNING HEAD: The Psychology of Corporate Rights}

that the opinions would have small immediate practical importance, both provoked substantial negative public responses. To be sure, part of the magnitude of these reactions is also explained by party cues and political partisanship (see, Nicholson \& Hansford, 2014). But it is not clear that such cueing effects can explain the public's receptivity to adverse partisan polemics concerning these decisions.

The results of the present study, by contrast, identify with greater precision a gap between the corporate rights as recognized by the Court in those cases as a matter of constitutional or statutory law and the corporate rights that both liberal and conservative members of the public recognize. In each of our three studies, we identified a significant, and substantial, difference between the perceived importance of an individual right and the perceived importance of a corresponding corporate right. In every study, respondents expressed substantially more regard for individual over corporate rights. This result, moreover, held, even in respect to corporate entities that might be thought ex ante to have a peculiarly strong claim to a given right-such as churches in regard to religious liberty or newspapers in regard to free speech. Such entities, in each of the three studies, were thought by respondents to have better claims to rights than other corporate entities. But in no case did support for any kind of corporate right equal in strength support for any kind of individual right.

This strong and consistent result suggests one reason for the magnitude of the public outcry after Citizens' United and Hobby Lobby. Indeed, our results may understate the gap between elite judicial and popular preferences. Our research design sought respondents' judgments of rights - without specifying whether these rights were constitutional, statutory, or even legal in nature. We chose this design in order to avoid the introduction of a level of 


\section{RUNNING HEAD: The Psychology of Corporate Rights}

precision greater than that plausibly to be expected from non-lawyer members of the public. But the results might be interpreted as evidence of public adversity to recognition of any speech, religious liberty, or privacy rights, legal or moral, in most corporate entities.

Intriguingly, our study suggests that although liberals and conservatives diverge in certain respects to the recognition of corporate rights to religious freedom, speech, and privacy, there is no clear liberal-conservative gap regarding the bottom-line judgment as to whether corporate entities of whatever sort should secure such rights. To the contrary, both liberals and conservatives have a similar preference for individual over corporate rights. Again, this result bears on understandings of the Supreme Court's interventions in this field. Several studies demonstrate that the Supreme Court is in some way, shape, or form, seen as a partisan actor (for a summary of the research, see Bartels \& Johnson, 2013; Nicholson \& Hansford, 2014). Nevertheless, the Court's recent promotion of corporate rights is out of step with both liberal and conservative samples of the public. To the extent that the Court is responsive to public judgments of corporate rights, therefore, it is possible that it is being responsive to a narrower, perhaps elite, perspective (cf. Dahl, 1957).

Nevertheless, liberal and conservative respondents did differ in one regard: Among conservatives, the belief that an individual right matters is positively correlated to the belief that corporate rights matter. Among liberals, in contrast, the belief that an individual right matters is negative correlated with the belief that a corporate right matters. It is easier to understand the result for conservative respondents here, where results appear to be motivated by beliefs over importance of a given right. With respect to liberals, it might be hypothesized that respondents presumed a conflict between individual and corporate rights. Only when an individual right was not recognized was the path open to recognition of a 


\section{RUNNING HEAD: The Psychology of Corporate Rights}

corporate right. Further research, however, is necessary to understand the relationship of political preferences to corporate rights.

Furthermore, our results shed some light on the psychological mechanisms underlying people's desire to give rights to organizations. Unlike the logic offered by many American businesses that petition to the Court for an intrinsic recognition of their constitutional rights as businesses, it seems that the public is less driven by the desire to protect the rights of businesses per-se, but rather views them as an instrument to protect the rights of individuals.

The current study has further implications for an understanding of the Supreme Court. Our results suggest that the public holds a consistent gap between corporate an individual rights - a gap that is consistently diminished in the ruling of the Supreme Court. Prior work, however, suggests that an intervention by the Court can change public opinion in respect to an issue (see, e.g., Hoekstra, 1995). There is also a debate in the literature as to whether public support for the Court is a function of perceived its compliance with procedural and legalistic norms (Gibson et al., 1998; Zink et al., 2009), or its conformity with observers' policy preferences (Braman \& Fontana, 2013). Further research needs to elaborate whether the Court's decisions (in cases like Hobby Lobby and others) change public views about corporate rights to religious or public damage public support in the Supreme Court (or both).

No less important, the studies presented here also provide a systematic exploration of the psychology of collective, and specifically corporate, rights. Expanding on previous work demonstrating that people encounter difficulties in attributing mind to collectives, and that these difficulties are translated into diminished perception of moral agency, our results 
show that the same difficulties also impact moral patiency. In other words, it is difficult to see non-human artificial collectives as deserving to the same scope of moral protection as real people do.

\section{Conclusion}

This study has examined public preferences over three kinds of corporate rights. Its central result is the strong priority of individual over corporate rights-regardless of the political preferences of the respondent or the nature of the corporate entities. As well as pointing to one explanation for recent antipathy to Supreme Court decisions on corporate rights, this result suggests a deep-seated individualism when it comes to recognizing rights that are central to American constitutional law. 
Figure 1: Religious Rights of Owners vs. Employees vs. Company

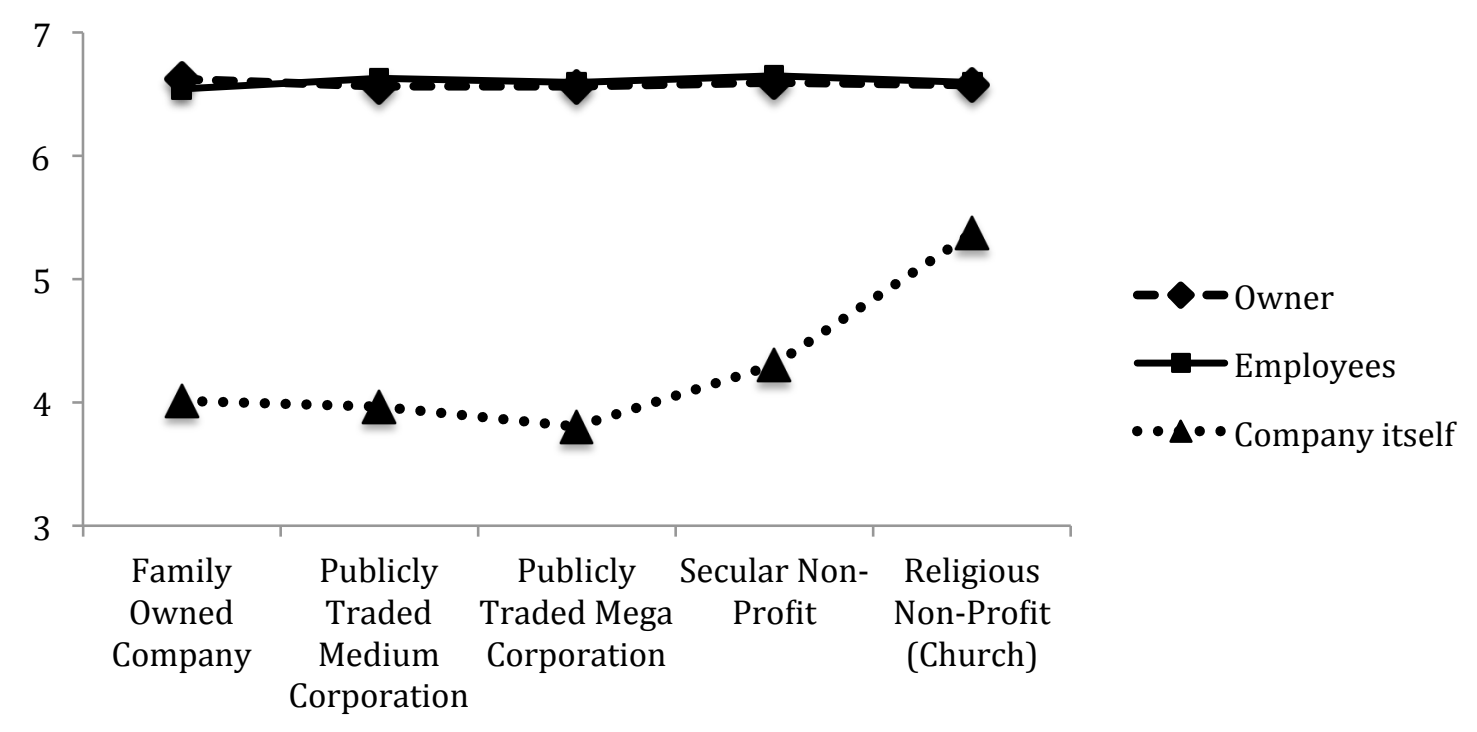

Study 1 results. Y axis represents perceived deservingness of religious liberty rights on a scale of 1 to 7 . 
Figures 2a \& 2b: Religious Rights of Owners vs. Employees vs. Company by Political Ideology. Y-axis represents perceived deservingness of religious liberty rights on a scale of 1 to 7.

Figure 2a: Liberals

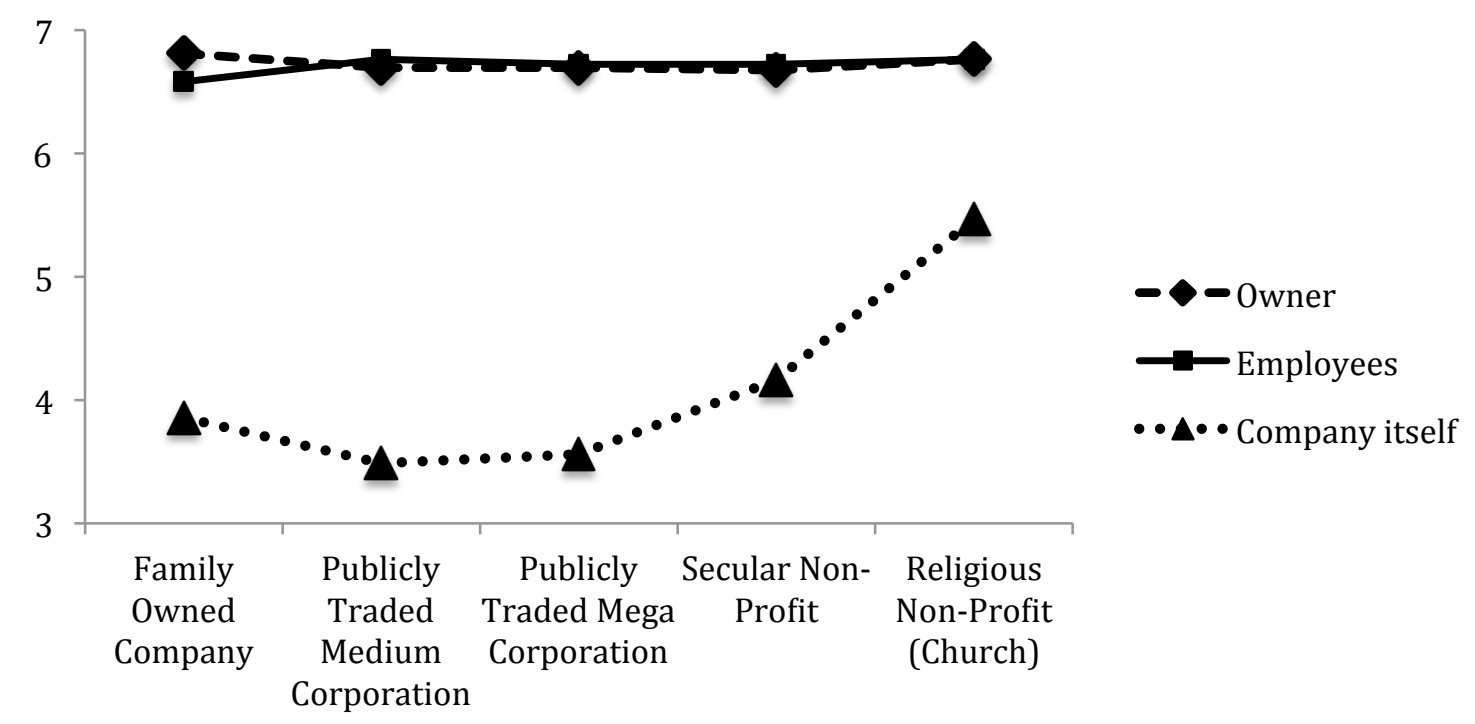

Figure 2b: conservatives

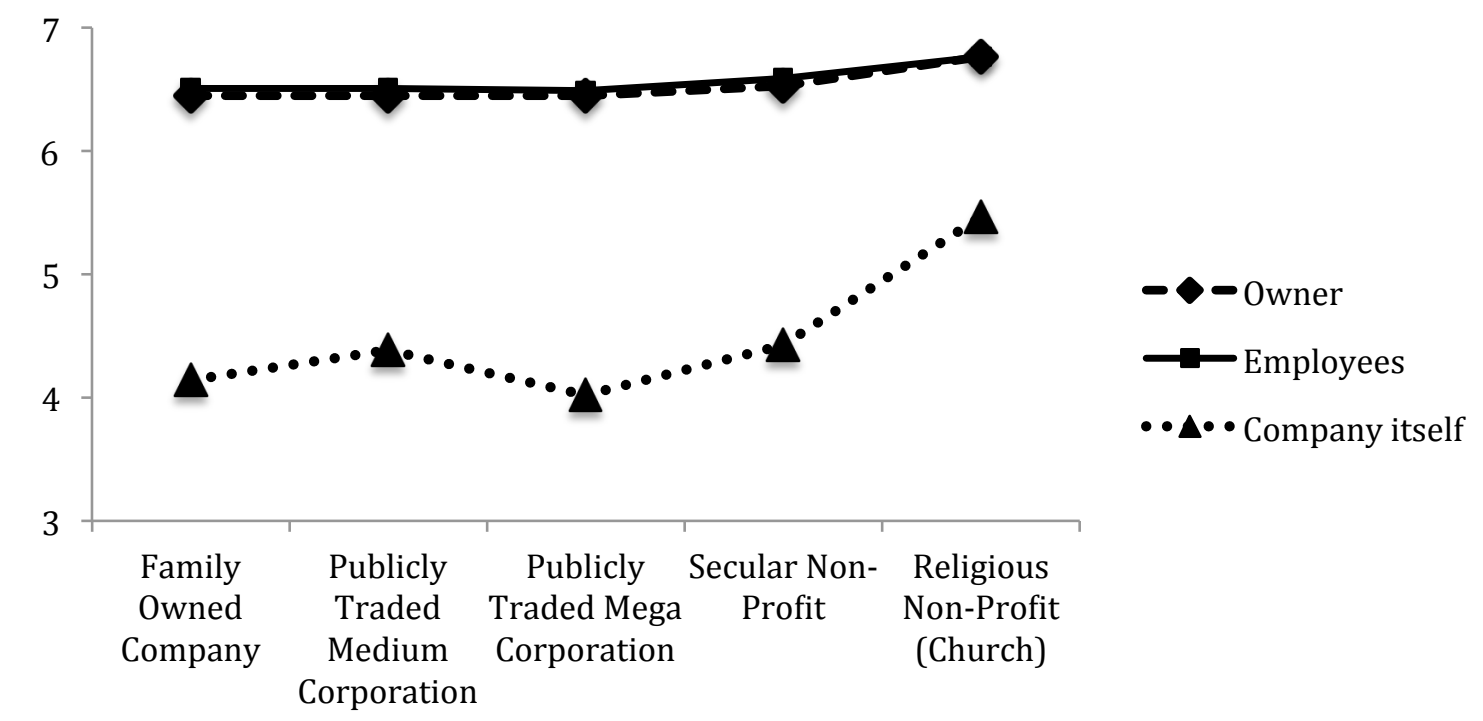


Figure 3: Perception of company rights by perception of employee rights and political ideology

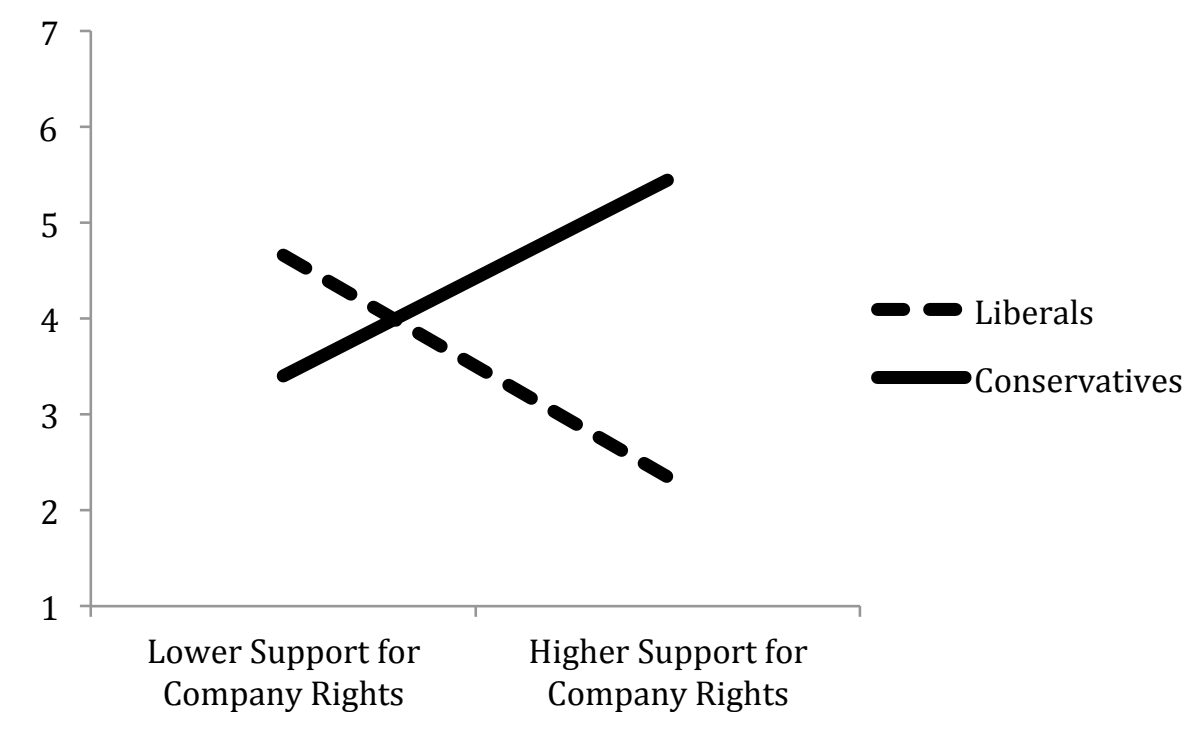

Figure 3: Support for company rights as function of support for employee rights and political ideology (study 1). Graph is plotted based on +/- $1 \mathrm{SD}$ from the sample mean. 
Figure 4: Privacy rights of Owners vs. Employees vs. Company

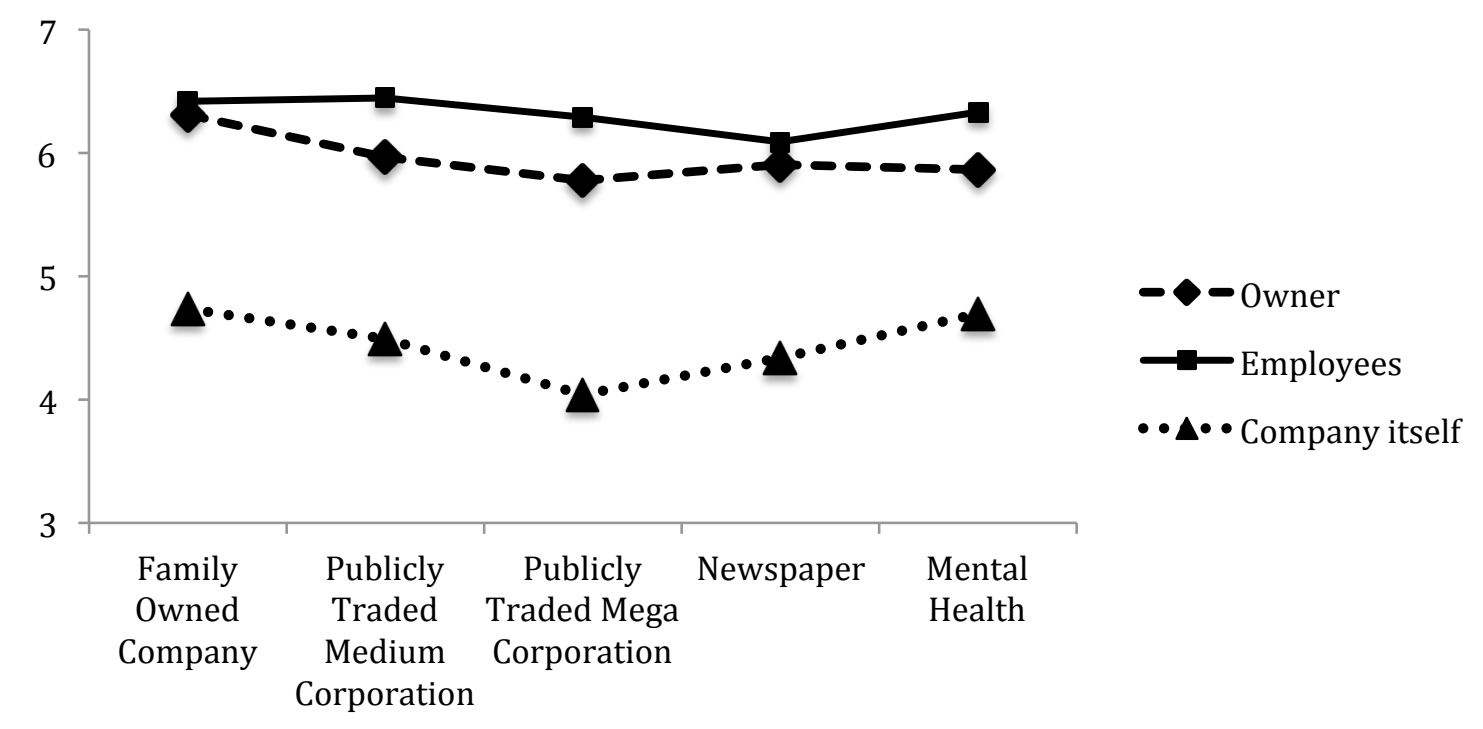

Study 2 results. Y-axis represents perceived deservingness of privacy rights on a scale of 1 to 7 . 
Figure 5: Free speech rights of Owners vs. Employees vs. Company

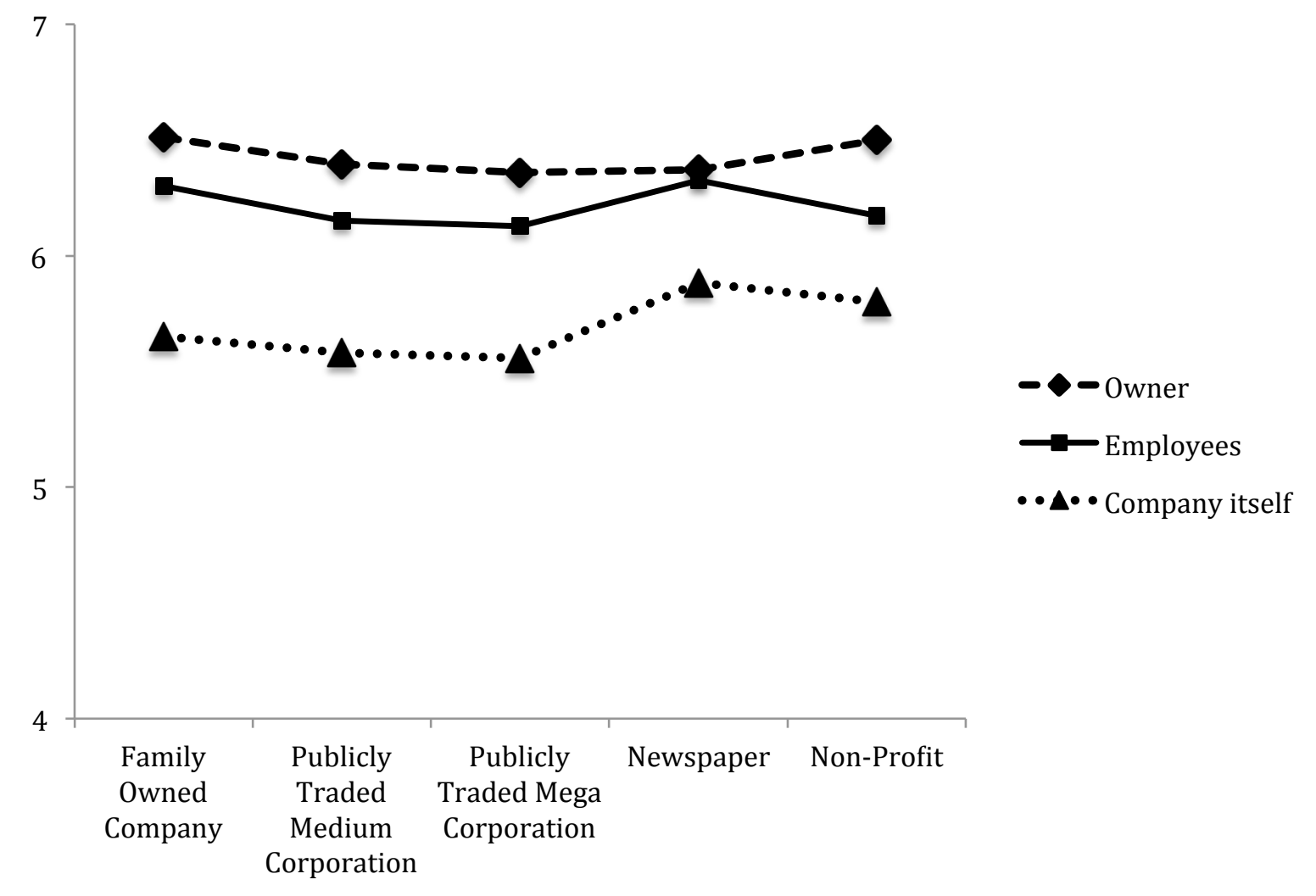

Study 3 results. Y-axis represents perceived deservingness of free speech rights on a scale of 1 to 7 . 
RUNNING HEAD: The Psychology of Corporate Rights

\section{Table 1}

The connection between desire to protect American Citizens and American businesses and granting free speech rights of companies (study 3)

\begin{tabular}{lcccc}
\hline Mega Corporation & $B$ & $S E$ & $\beta$ & Sig. \\
\hline Protect Citizens & .404 & .2 & .452 & $=.05$ \\
Protect Businesses & .311 & .23 & .306 & $=\mathrm{n} / \mathrm{s}$
\end{tabular}

\begin{tabular}{lcccc}
\hline Mental Health Center & & & & \\
& $B$ & $S E$ & $\beta$ & Sig. \\
\hline Protect Citizens & .603 & .14 & .53 & $<.001$ \\
Protect Businesses & .176 & .11 & .199 & $=\mathrm{n} / \mathrm{s}$
\end{tabular}

\begin{tabular}{lcccc}
\hline Newspaper & $B$ & $S E$ & $\beta$ & Sig. \\
\hline Protect Citizens & .579 & .15 & .404 & $<.001$ \\
Protect Businesses & .375 & .1 & .396 & $<.001$
\end{tabular}




\section{Supplemented Materials:}

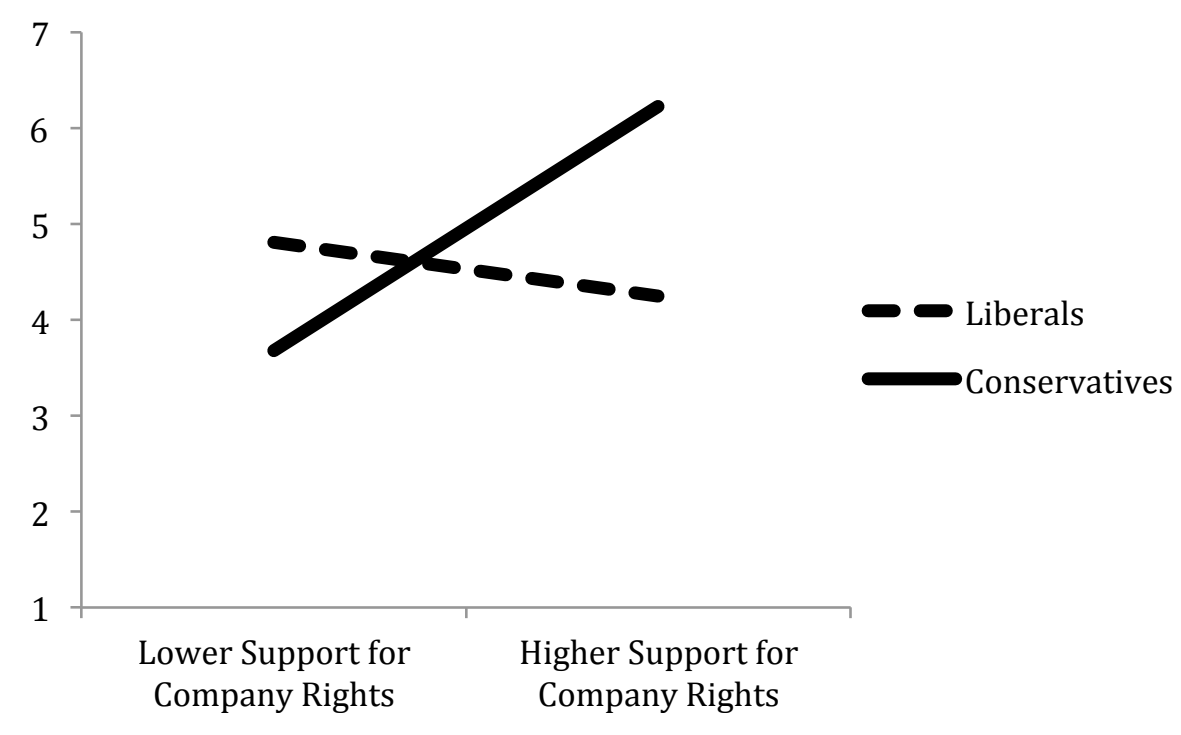

Figure 1: Support for company's privacy rights as function of support for employee rights (study 2) and political ideology. Graph is plotted based on +/- $1 \mathrm{SD}$ from the sample mean. 


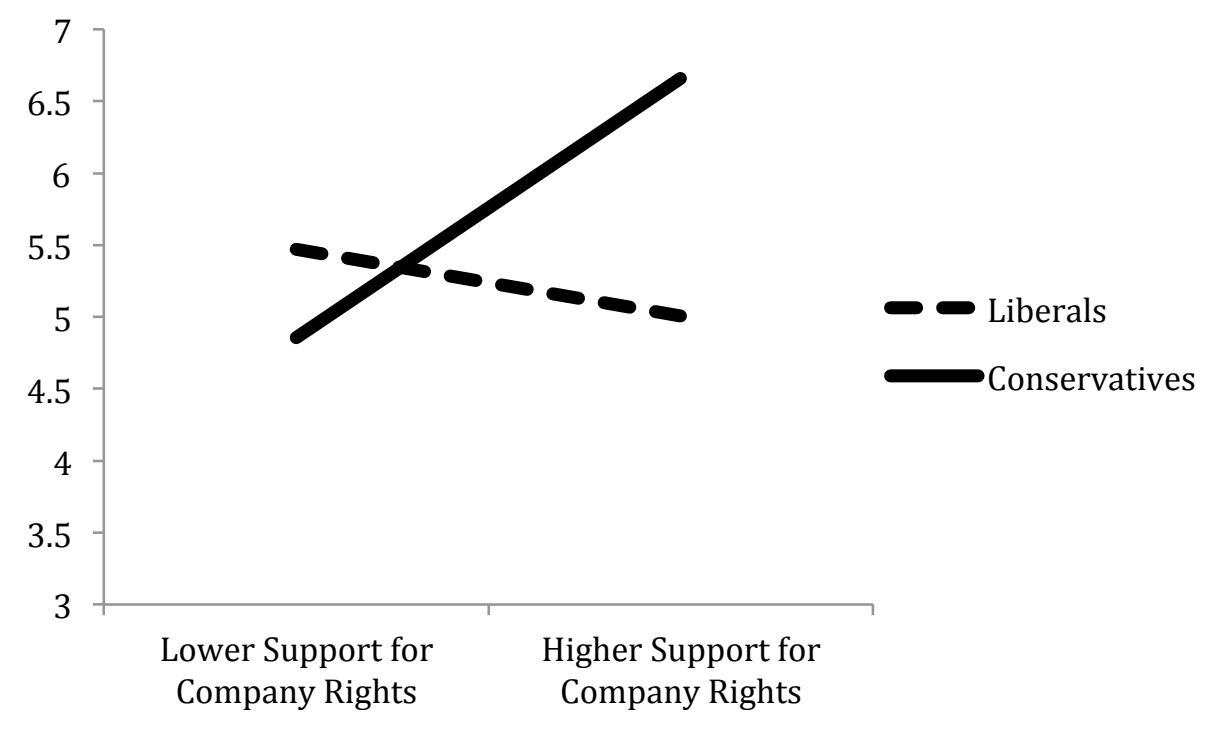

Figure 2: Support for company's free speech rights as function of support for employee rights (study 3) and political ideology. Graph is plotted based on +/- 1 SD from the sample mean. 


\section{Reference}

Bartels, B. L., \& Johnston, C. D. (2013). On the Ideological Foundations of Supreme Court Legitimacy in the American Public. American Journal of Political Science, 57(1), 184199. doi:10.1111/j.1540-5907.2012.00616.x

Bhagwat, A. (2010). Associational Speech. Yale Law Journal, 120, 978.

Blackstone, B. (2013). An Analysis of Policy-Based Congressional Responses to the U.S. Supreme Court's Constitutional Decisions. Law \& Society Review, 47(1), 199-228.

Burwell v. Hobby Lobby, 573 U.S. (2014).

Carroll, R. (2013, August 30). Microsoft and Google to sue over US surveillance requests. The Guardian. Retrieved from http:/www.theguardian.com/law/2013/aug/31/microsoftgoogle-sue-us-fisa.

Coase, R. H. (1937). The Nature of the Firm. Economica, 4(16), 386-405. doi:10.1111/j.

Citizens United v. FEC 130 S. Ct. 876 (2010).

Dahl, R. (1957). Decisionmaking in a Democracy: The Supreme Court as National Policymaker. Journal of Public Law, 6: 279-95.

Davidson, L. A., Pettis, C. T., Joiner, A. J., Cook, D. M., \& Klugman, C. M. (2010). Religion and conscientious objection: A survey of pharmacists' willingness to dispense medications. Social Science \& Medicine, 71(1), 161-165.

doi:10.1016/j.socscimed.2010.03.027

Dewey, J. (1926). The Historic Background of Corporate Legal Personality. The Yale Law Journal, 35(6), 655-673. doi:10.2307/788782

Dubber, M. D. (2013). The Comparative History and Theory of Corporate Criminal Liability. New Criminal Law Review: An International and Interdisciplinary Journal, 
16(2), 203-240. doi:10.1525/nclr.2013.16.2.203.

Easterbrook, F. H., \& Fischel, D. R. (1989). The Corporate Contract. Columbia Law Review, 89(7), 1416-1448. doi:10.2307/1122807.

FEC v. Massachusetts Citizens for Life, Inc., 479 U.S. 238 (1986).

FEC v. Wisconsin Right to Life, 551 U.S. 449 (2007).

Fontana, D., \& Braman, D. (2012). Judicial Backlash or Just Backlash: Evidence from a National Experiment. Columbia Law Review, 112(4), 731-799.

Garrett, B. L. (2007). Structural Reform Prosecution. Virginia Law Review, 93(4), 853-957.

Garrett, B. L. (forthcoming 2014). The Constitutional Standing of Corporations. University of Pennsylvania Law Review.

Gray, K., \& Wegner, D. M. (2009). Moral typecasting: Divergent perceptions of moral agents and moral patients. Journal of Personality and Social Psychology, 96(3), 505520. doi:10.1037/a0013748.

Gray, K., Young, L., \& Waytz, A. (2012). Mind perception is the essence of morality. Psychological Inquiry, 23(2), 101-124.

Green, L. (1991). Two Views of Collective Rights. Canadian Journal of Law and Jurisprudence, 4, 315 .

Hart, O., \& Moore, J. (1988). Incomplete Contracts and Renegotiation. Econometrica, 56(4), 755-785. doi:10.2307/1912698.

Henning, P. J. (1995). Conundrum of Corporate Criminal Liability: Seeking a Consistent Approach to the Constitutional Rights of Corporations in Criminal Prosecutions, The. Tennessee Law Review, 63, 793.

Hoekstra, V. J. (1995). The Supreme Court and Opinion Change An Experimental Study of 
the Court's Ability to Change Opinion. American Politics Research, 23(1), 109-129. doi:10.1177/1532673X9502300106.

Horwitz, M. J. (1985). Santa Clara Revisited: The Development of Corporate Theory. West Virginia Law Review, 88, 173.

Isaacs, T. (2013). Corporate Agency and Corporate Wrongdoing. New Criminal Law Review: An International and Interdisciplinary Journal, 16(2), 241-260. doi:10.1525/nclr.2013.16.2.241.

Jensen, M. C., \& Meckling, W. H. (1976). Theory of the firm: Managerial behavior, agency costs and ownership structure. Journal of Financial Economics, 3(4), 305-360. doi:10.1016/0304-405X(76)90026-X.

Kang, J., \& Banaji, M.R. (2006) Fair measures: a behavioral realist revision of "affirmative action”. 376 Calif Law Rev 94,1063-1118.

Kang, M. S. (2012). The End of Campaign Finance Law. Virginia Law Review, 98(1), 1-65.

Klausner, M. (1995). Corporations, Corporate Law, and Networks of Contracts. Virginia Law Review, 81(3), 757-852. doi:10.2307/1073499.

Krieger, L.B., \& Fiske, S.T. (2006) Behavioral realism in employment discrimination law: implicit bias 384 and disparate treatment. Calif Law Rev 94, 997-1062.

Laufer, W. S. (2006). Corporate Bodies and Guilty Minds: The Failure of Corporate Criminal Liability (1 edition.). Chicago: University Of Chicago Press.

Lee, I. B. (2009). Citizenship and the Corporation. Law \& Social Inquiry, 34(1), 129-169. Levitt, J. (2010). Confronting the Impact of "Citizens United." Yale Law \& Policy Review, $29(1), 217-234$.

McCutcheon v. Federal Election Commission, 572 U.S. (2014). 
Menon, T., Morris, M. W., Chiu, C., \& Hong, Y. (1999). Culture and the construal of agency: Attribution to individual versus group dispositions. Journal of Personality and Social Psychology, 76(5), 701-717. doi:10.1037/0022-3514.76.5.701.

Mentovich, A. \& Cerf, M. (2014). The Psychology of Corporate Crime and Punishment, to appear in J. Vogel \& D. Brodowski (Eds.) Corporate Criminal Liability, Springer.

Mentovich, A., \& Jost, J. T. (2008) The ideological "Id"? System justification and the unconscious perpetuation of inequality. Conn Law Rev 40, 1095-1116.

Morewedge, C. K., Chandler, J. J., Smith, R., Schwarz, N., \& Schooler, J. (2013). Lost in the crowd: Entitative group membership reduces mind attribution. Consciousness and Cognition, 22(4), 1195-1205. doi:10.1016/j.concog.2013.08.002.

Nicholson, S. P., \& Hansford, T. G. (2014). Partisans in Robes: Party Cues and Public Acceptance of Supreme Court Decisions. American Journal of Political Science, 58(3), 620-636. doi:10.1111/ajps.12091.

Perlroth, N., \& Shane, S. (2013, October 2). As F.B.I. Pursued Snowden, an E-Mail Service Stood Firm. The New York Times. Retrieved from http://www.nytimes.com/2013/10/03/us/snowdens-e-mail-provider-discusses-pressurefrom-fbi-to-disclose-data.html.

Sachs, B. I. (2012). Unions, Corporations, and Political Opt-Outs, after Citizens United. Columbia Law Review, 112(4), 800-869.

Santa Clara County v. Southern Pacific Railroad Company, 118 U.S. 394 (1886)

Solove, D. J. (2001). Digital Dossiers and the Dissipation of Fourth Amendment Privacy. Southern California Law Review, 75, 1083.

Speechnow v. FEC, 599 F.3d 686 (D.C. Cir. 2010). 
RUNNING HEAD: The Psychology of Corporate Rights

Steyn, J. (2004). Guantanamo Bay: The Legal Black Hole. International \& Comparative Law Quarterly, 53(01), 1-15. doi:10.1093/iclq/53.1.1

Tillman Act of 1907 (2 U.S.C. § 441b)

Tyler, T. R., \& Blader, S. L. (2005). Can Businesses Effectively Regulate Employee Conduct? The Antecedents of Rule Following in Work Settings. Academy of Management Journal, 48(6), 1143-1158. doi:10.5465/AMJ.2005.19573114.

Tyler ,T.R., \& Mentovich, A. (2011) Punishing collective entities. J Law Policy 19:203230.

Velasquez, M. G. (1983). Abstract of "Why Corporations Are Not Morally Responsible for Anything They Do.” Business and Professional Ethics Journal, 2(4), 99-99.

Villalonga, B., \& Amit, R. (2010). Family Control of Firms and Industries. Financial Management, 39(3), 863-904.

Waytz, A., \& Young, L. (2011). The Group-Member Mind Trade-Off Attributing Mind to Groups Versus Group Members. Psychological Science, 0956797611423546. doi:10.1177/0956797611423546.

Wheaton College v. Burwell, 573 U.S. (2014).

Williamson, O. E. (2002). The Theory of the Firm as Governance Structure: From Choice to Contract. The Journal of Economic Perspectives, 16(3), 171-195.

Zink, J. R., Spriggs, J. F. I., \& Scott, J. T. (2009). Courting the Public: The Influence of Decision Attributes on Individuals' Views of Court Opinions. The Journal of Politics, 71(03), 909-925. doi:10.1017/S0022381609090793 
Readers with comments may address them to:

Professor Aziz Huq

University of Chicago Law School

1111 East 60th Street

Chicago, IL 60637

huq@uchicago.edu 


\section{The University of Chicago Law School Public Law and Legal Theory Working Paper Series}

For a listing of papers 1-400 please go to http://www.law.uchicago.edu/publications/papers/publiclaw.

401. Gary Becker, François Ewald, and Bernard Harcourt, "Becker on Ewald on Foucault on Becker” American Neoliberalism and Michel Foucauilt’s 1979 Birth of Biopolitics Lectures, September 2012

402. M. Todd Henderson, Voice versus Exit in Health Care Policy, October 2012

403. Aziz Z. Huq, Enforcing (but Not Defending) “Unconstitutional” Laws, October 2012

404. Lee Anne Fennell, Resource Access Costs, October 2012

405. Brian Leiter, Legal Realisms, Old and New, October 2012

406. Tom Ginsburg, Daniel Lnasberg-Rodriguez, and Mila Versteeg, When to Overthrow Your Government: The Right to Resist in the World's Constitutions, November 2012

407. Brian Leiter and Alex Langlinais, The Methodology of Legal Philosophy, November 2012

408. Alison L. LaCroix, The Lawyer's Library in the Early American Republic, November 2012

409. Alison L. LaCroix, Eavesdropping on the Vox Populi, November 2012

410. Alison L. LaCroix, On Being “Bound Thereby,” November 2012

411. Alison L. LaCroix, What If Madison had Won? Imagining a Constitution World of Legislative Supremacy, November 2012

412. Jonathan S. Masur and Eric A. Posner, Unemployment and Regulatory Policy, December 2012

413. Alison LaCroix, Historical Gloss: A Primer, January 2013

414. Jennifer Nou, Agency Self-Insulation under Presidential Review, January 2013

415. Aziz Z. Huq, Removal as a Political Question, February 2013

416. Adam B. Cox and Thomas J. Miles, Policing Immigration, February 2013

417. Anup Malani and Jonathan S. Masur, Raising the Stakes in Patent Cases, February 2013

418. Ariel Porat and Lior Strahilevits, Personalizing Default Rules and Disclosure with Big

Data, February 2013

419. Douglas G. Baird and Anthony J. Casey, Bankruptcy Step Zero, February 2013

420. Alison L. LaCroix, The Interbellum Constitution and the Spending Power, March 2013

421. Lior Jacob Strahilevitz, Toward a Positive Theory of Privacy Law, March 2013

422. Eric A. Posner and Adrian Vermeule, Inside or Outside the System? March 2013

423. Nicholas G. Stephanopoulos, The Consequences of Consequentialist Criteria, March 2013

424. Aziz Z. Huq, The Social Production of National Security, March 2013

425. Aziz Z. Huq, Federalism, Liberty, and Risk in NIFB v. Sebelius, April 2013

426. Lee Anne Fennell, Property in Housing, April 2013

427. Lee Anne Fennell, Crowdsourcing Land Use, April 2013

428. William H. J. Hubbard, An Empiritcal Study of the Effect of Shady Grove v. Allstate on Forum Shopping in the New York Courts, May 2013

429. Daniel Abebe and Aziz Z. Huq, Foreign Affairs Federalism: A Revisionist Approach, May 2013

430. Albert W. Alschuler, Lafler and Frye: Two Small Band-Aids for a Festering Wound, June 2013

431. Tom Ginsburg, Jonathan S. Masur, and Richard H. McAdams, Libertarian Paternalism, Path Dependence, and Temporary Law, June 2013

432. Aziz Z. Huq, Tiers of Scrutiny in Enumerated Powers Jurisprudence, June 2013 
433. Bernard Harcourt, Beccaria's On Crimes and Punishments: A Mirror of the History of the Foundations of Modern Criminal Law, July 2013

434. Zachary Elkins, Tom Ginsburg, and Beth Simmons, Getting to Rights: Treaty

Ratification, Constitutional Convergence, and Human Rights Practice, July 2013

435. Christopher Buccafusco and Jonathan S. Masur, Innovation and Incarceration: An Economic Analysis of Criminal Intellectual Property Law, July 2013

436. Rosalind Dixon and Tom Ginsburg, The South African Constitutional Court and SocioEconomic Rights as 'Insurance Swaps', August 2013

437. Bernard E. Harcourt, The Collapse of the Harm Principle Redux: On Same-Sex Marriage, the Supreme Court's Opinion in United States v. Windsor, John Stuart Mill's essay On Liberty (1859), and H.L.A. Hart's Modern Harm Principle, August 2013

438. Brian Leiter, Nietzsche against the Philosophical Canon, April 2013

439. Sital Kalantry, Women in Prison in Argentina: Causes, Conditions, and Consequences, May 2013

440. Becker and Foucault on Crime and Punishment, A Conversation with Gary Becker, François Ewald, and Bernard Harcourt: The Second Session, September 2013

441. Daniel Abebe, One Voice or Many? The Political Question Doctrine and Acoustic Dissonance in Foreign Affairs, September 2013

442. Brian Leiter, Why Legal Positivism (Again)? September 2013

443. Nicholas Stephanopoulos, Elections and Alignment, September 2013

444. Elizabeth Chorvat, Taxation and Liquidity: Evidence from Retirement Savings, September 2013

445. Elizabeth Chorvat, Looking Through' Corporate Expatriations for Buried Intangibles, September 2013

446. William H. J. Hubbard, A Theory of Pleading, Litigation, and Settlement, November 2013

447. Tom Ginsburg, Nick Foti, and Daniel Rockmore, "We the Peoples”: The Global Origins of Constitutional Preambles, March 2014

448. Lee Anne Fennell and Eduardo M. Peñalver, Exactions Creep, December 2013

449. Lee Anne Fennell, Forcings, December 2013

450. Jose Antonio Cheibub, Zachary Elkins, and Tom Ginsburg, Beyond Presidentialism and Parliamentarism, December 2013

451. Nicholas Stephanopoulos, The South after Shelby County, October 2013

452. Lisa Bernstein, Trade Usage in the Courts: The Flawed Conceptual and Evidentiary Basis of Article 2's Incorporation Strategy, November 2013

453. Tom Ginsburg, Political Constraints on International Courts, December 2013

454. Roger Allan Ford, Patent Invalidity versus Noninfringement, December 2013

455. M. Todd Henderson and William H.J. Hubbard, Do Judges Follow the Law? An Empirical Test of Congressional Control over Judicial Behavior, January 2014

456. Aziz Z. Huq, Does the Logic of Collective Action Explain Federalism Doctrine? January 2014

457. Alison L. LaCroix, The Shadow Powers of Article I, January 2014

458. Eric A. Posner and Alan O. Sykes, Voting Rules in International Organizations, January 2014

459. John Rappaport, Second-Order Regulation of Law Enforcement, April 2014

460. Nuno Garoupa and Tom Ginsburg, Judicial Roles in Nonjudicial Functions, February 2014

461. Aziz Huq, Standing for the Structural Constitution, February 2014

462. Jennifer Nou, Sub-regulating Elections, February 2014

463. Albert W. Alschuler, Terrible Tools for Prosecutors: Notes on Senator Leahy’s Proposal to "Fix" Skilling v. United States, February 2014 
464. Aziz Z. Huq, Libertarian Separation of Powers, February 2014

465. Brian Leiter, Preface to the Paperback Edition of Why Tolerate Religion? February 2014

466. Jonathan S. Masur and Lisa Larrimore Ouellette, Deference Mistakes, March 2014

467. Eric A. Posner, Martii Koskenniemi on Human Rights: An Empirical Perspective, March 2014

468. Tom Ginsburg and Alberto Simpser, Introduction, chapter 1 of Constitutions in Authoritarian Regimes, April 2014

469. Aziz Z. Huq, Habeas and the Roberts Court, April 2014

470. Aziz Z. Huq, The Function of Article V, April 2014

471. Aziz Z. Huq, Coasean Bargaining over the Structural Constitution, April 2014

472. Tom Ginsburg and James Melton, Does the Constitutional Amendment Rule Matter at All? Amendment Cultures and the Challenges of Measuring Amendment Difficulty, May 2014

473. Eric A. Posner and E. Glen Weyl, Cost-Benefit Analysis of Financial Regulations: A Response to Criticisms, May 2014

474. Paige A. Epstein, Addressing Minority Vote Dilution Through State Voting Rights Acts, February 2014

475. William Baude, Zombie Federalism, April 2014

476. Albert W. Alschuler, Regarding Re's Revisionism: Notes on "The Due Process Exclusionary Rule", May 2014

477. Dawood I. Ahmed and Tom Ginsburg, Constitutional Islamization and Human Rights: The Surprising Origin and Spread of Islamic Supremacy in Constitutions, May 2014

478. David Weisbach, Distributionally-Weighted Cost Benefit Analysis: Welfare Economics Meets Organizational Design, June 2014

479. William H. J. Hubbard, Nuisance Suits, June 2014

480. Saul Levmore and Ariel Porat, Credible Threats, July 2014

481. Brian Leiter, The Case Against Free Speech, June 2014

482. Brian Leiter, Marx, Law, Ideology, Legal Positivism, July 2014

483. John Rappaport, Unbundling Criminal Trial Rights, August 2014

484. Daniel Abebe, Egypt, Ethiopia, and the Nile: The Economics of International Water Law, August 2014

485. Albert W. Alschuler, Limiting Political Contributions after Mccutcheon, Citizens United, and SpeechNow, August 2014

486. Zachary Elkins, Tom Ginsburg, and James Melton, Comments on Law and Versteeg's "The Declining Influence of the United States Constitution," August 2014

487. William H. J. Hubbard, The Discovery Sombrero, and Other Metaphors for Litigation, September 2014

488. Genevieve Lakier, The Invention of Low-Value Speech, September 2014

489. Lee Anne Fennell and Richard H. McAdams, Fairness in Law and Economics: Introduction, October 2014

490. Thomas J. Miles and Adam B. Cox, Does Immigration Enforcement Reduce Crime? Evidence from 'Secure Communities', October 2014

491. Ariel Porat and Omri Yadlin, Valuable Lies, October 2014

492. Laura M. Weinrib, Civil Liberties outside the Courts, October 2014

493. Nicholas Stephanopoulos and Eric McGhee, Partisan Gerrymandering and the Efficiency Gap, October 2014

494. Nicholas Stephanopoulos, Aligning Campaign Finance Law, October 2014

495. John Bronsteen, Christopher Buccafusco and Jonathan S. Masur, Well-Being and Public Policy, November 2014

496. Lee Anne Fennell, Agglomerama, December 2014 
497. Avital Mentovich, Aziz Z. Huq, and Moran Cerf, The Psychology of Corporate Rights, December 2014 